\title{
Biobanking of a Marine Invertebrate Model Organism: The Sea Urchin
}

\author{
Estefania Paredes \\ Received: 18 November 2015; Accepted: 12 January 2016; Published: 22 January 2016 \\ Academic Editor: Magnus Wahlberg \\ Fundamental and Applied Cryobiology Group, Department of Biochemistry and Cellular and Molecular \\ Biology, University of Tennessee, Knoxville, TN 37996, USA; eparedes@utk.edu; Tel.: +1-865-974-9961
}

\begin{abstract}
The sea urchin has long been used as an invertebrate model organism in developmental biology, membrane transport and sperm oocyte interactions, and for the assessment of marine pollution. This review explores the effects of cryopreservation and biobanking in the biology and development of sea urchins, all the way from germaplasm through to juveniles. This review will provide an integral view of the process and all that is known so far about the biology of cryopreserved sea urchins, as well as provide an insight on the applications of the biobanking of these model organisms.
\end{abstract}

Keywords: model organisms; test organisms; cryopreservation; sea urchin; marine invertebrate; cryopreservation

\section{Introduction}

Sea urchins can be found from shallow shores to deep waters. There are more than 700 known species widespread within the five oceans [1]. Some sea urchins are a key group of herbivores due to their grazing control of the macro algal cover, playing an important role in the functioning, dynamics and structure of benthic assemblages [2], while others present a omnivorous feeding behavior [3]. Sea urchins are well-known as models for studying larvae biology and development; they have been used as a model organism to study reproduction and early cell differentiation processes, sperm oocyte interactions, and efflux transport and apoptosis [3-6]

Sea urchins have also been extensively used in ecotoxicology. Current strategies of water quality assessment integrate the chemical analysis with biological parameters to evaluate the effects of pollution on living resources $[7,8]$ Due to the sensitivity of gametes and early stages of development to pollutants present in seawater- even at very low concentrations-sea urchin sperm and embryo-larval bioassays have been routinely used for water quality assessment for decades $[7,9,10]$.

Most sea urchins are edible. There are few toxic species; there are venomous species in the Indo-Pacific including the Red Sea (Diadema setosum, Toxopneustes pileolus, Tripneustes gratilla), in the Caribbean (Diadema antillarum), and in the tropical and subtropical Atlantic coasts of South America and Africa (Tripneustes ventricosus). Despite these few being toxic, not many sea urchin species are consumed. There is evidence that those known to be edible have been collected from the oceans as early as 2400 B.C. [3]. With modern times, sea urchin fisheries have flourished around the world, and most of them still remain quite traditional. With the actual means of transportation, distribution and the increasing value or sea urchin roe, the rate of extraction is leading to the overfishing of many populations [11]. Due to the concern about the collapse of natural populations [3], there has been active research in the following fields: echinoculture or land-based culture [12]; larval and juvenile feeding [13,14]; artificial feed [15]; larval rearing systems [16]; gonad enhancement [17-19]; and wild stock enhancement [20]. 
Sea urchins are being collected from the sea, consumed as food, used for bioassays and kept in research facilities all over the world. Cryopreservation can be a very powerful biotechnological tool to enhance the use of sea urchins as a model species for research, enhance the use of embryo-larval bioassays, preserve genetic resources against extinction and increase the culinary interest in sea urchin roe. The development of cryopreservation protocols for different sea urchin cell types will allow the establishment of biobanks, providing year-round access to high quality material, regardless of the reproductive season, the oceanic, meteorological and environmental conditions that can be a source of uncertainty and variability [21] Access to cryopreserved embryos will allow using these model organisms in laboratories all around the world, regardless of their facilities or their proximity to a natural population of sea urchins. It will be a very useful tool for aquaculture production, fisheries conservation and wild stock enhancement [10], allowing spat supply all year round without the need of conditioning broodstock for out of season reproduction-which is expensive, time consuming and often unfruitful [22]. It will also provide flexibility for selective breeding programs [22,23] by allowing crossings of individuals from different reproductive seasons. Although gametes and/or embryo cryopreservation protocols have been successfully developed for many valuable species as sturgeons [24], salmonid fishes [25] due to their aquaculture interest, or marine invertebrates as oysters, mussels or abalone [22,26,27], arthropods, like the marine shrimps [28-30], little research has been carried out regarding sea urchin cryopreservation(example of development on Figure 1).

Gametes and embryo cryopreservation protocols and cryopreservation effects have been studied and published for 11 sea urchin species, the most common of which are Hemicentrotus pulcherrimus, Strongylocentrotus nudus and Stongylocentrotus intermedius by Asahina and Takahashi [31,32], Naidenko et al. [33] and Naidenko and Koltsova [34], Tetrapigus niger by Barros et al. [35,36], Evechinus chloroticus by Adams and Hessian [37] and Adams et al. [38] and Paracentrotus lividus embryos by Bellas and Paredes [39] and Paredes and Bellas [10].

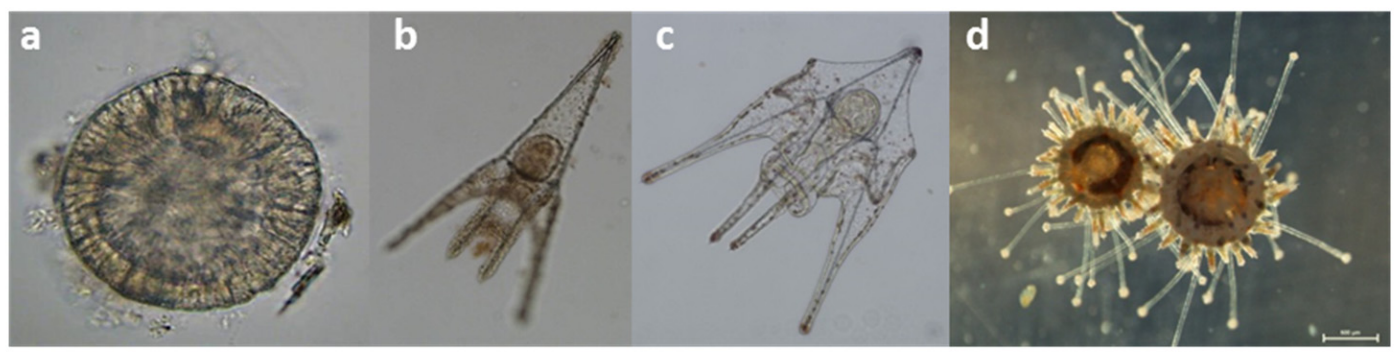

Figure 1. Development schedule: P. lividus at $20^{\circ} \mathrm{C}$ from cryopreserved blastula embryos all the way to settlement $(\mathbf{a}-\mathbf{c})$ and juveniles $(\mathbf{d})$. Larvae achieve competence to settle after 21 days in incubation. Competent larvae were transferred to previously-conditioned petri dishes for settlement for 18 days. (d.p.s: days post settlement). All the details of the larval rearing can be found at Paredes et al. [40].

\section{Principles of Cryopreservation}

Cryobiology is a well-developed and worldwide-recognized technique for achieving long-term storage of biological material at low temperatures. Cryopreservation consists of freezing, banking and thawing living organisms, cells or tissues in the presence of cryoprotecting agents (CPAs) [41]. Many chemicals have been identified as having cryoprotective action, for example, dimethyl sulfoxide $\left(\mathrm{Me}_{2} \mathrm{SO}\right)$, propylene glycol (PG), ethylene glycol (EG), glycerol (GLY), methanol (MetOH), sucrose (SUC) and other sugars or polyvinylpyrrolidone (PVP). It is critical to achieve a compromise between the ability of the CPA to protect the cells against cryopreservation, and the CPA toxicity $[39,42,43]$.

When cells are exposed to a solution containing a CPA, the differences in the osmotic pressure of the solution inside and outside the cell will cause an initial diffusion of water from the cell to equilibrate the osmotic pressures [44] At the same time, the higher concentration of the CPA in the external solution will cause the diffusion of the CPA into the cell. The process will stop once the 
concentration of the CPA equalize outside and inside the cell. At that point, the volume in equilibrium will be slightly larger than the initial due to the presence of CPA inside the cell [44].

The freezing point of the external solution will depend on the solution media and the CPAs present. Once the cooling starts the external media will freeze before the cells and water inside will be under its thermodynamic freezing point. Water below its freezing point is defined as supercooled and has a higher vapor pressure at a given temperature than the ice outside the cell $[41,45]$. As long as this difference in potential remains, water will slowly leave the cell and freeze externally, and the cell will dehydrate. Concentration of solutes inside the cell will increase and the potential reduced to reach the thermodynamic equilibrium, after which the cell will freeze without the formation of internal ice crystals, which will be lethal. Once successfully cryopreserved, the cells or embryos need to be transferred to liquid nitrogen for conservation.

Banking in liquid nitrogen $\left(-196^{\circ} \mathrm{C}\right)$ will ensure the conservation of cryopreserved cells as long as necessary [46,47]. At this low temperature, no chemical reactions take place and cellular metabolism is on hold. Once cells are stored in liquid nitrogen, their viability would only be affected either by background radiations, which at normal level will take 2000 years to become a hazard to stored cells [48], or human mishandling [49].

The fundamental steps in the cryopreservation process are:

1. Selection of the right CPA: It is necessary to know or study the toxic effects and toxicity thresholds of the different chemical compounds in order to select the right CPA or combinations of CPAs to be used in cryopreservation, as well as the temperature of addition and equilibration.

2. The addition and removal of CPAs: Factors such as membrane permeability, temperature, and osmotic excursions effects need to be taken into account.

3. Selecting the volume of the sample: The volume of the sample will affect the cooling and thawing rates and will also determine which programmable freezer to use and the liquid nitrogen storage needs.

4. Choosing/designing the right cryopreservation protocol: Determining the cooling rate/s, the temperature of seeding, the thawing rate and the ending point of the cooling are important key points.

5. Correct storage without temperature fluctuations: Samples should be continuously stored below their glass transition temperature; temperature excursions out of this range will result in recrystallization of the ice, a process in which large ice crystals grow at the expense of smaller ones, causing leading to reduced cell viability or even cell destruction.

\section{Biobanking of Model Organisms}

The idea of what a biobank is can be easily understood, although there are some different definitions and disagreements among scientists on the specifics [50]. Many scientific, medical, national and international agencies often refer to the biobanking of human biological material or genetic information. However, the idea of biobanking can and has been applied to animal biological material and genetic information. Biobanking for our purposes can be defined in a simple way: as a long-term biorepository for storage of biological material at low temperatures.

A model organism can be defined as a non-human species that has been extensively studied to understand different biological phenomena with the expectation that knowledge made in the model will provide insight into other organisms. There are several desired characteristics on a model organism: Ease of year-round breeding in the laboratory is one of the most important ones and sometimes quite complicated or expensive to achieve. Often characteristics such as short life cycle, well developed techniques for genetic manipulation, and simple living requirements are valuable when choosing a model organism to work with [51,52].

The design of cryopreservation protocols for the germaplasm model organism is the way to overcome the logistic issues of obtaining and maintaining those organisms-lowering the costly effort 
and reducing the time dedicated [53]. There are different model organisms. At one end, we have the classical models, which have most of their biological processes well studied. At the other end are the emerging model organisms, which might be well studied for particular biological phenomena but have attracted less interest, and therefore their biological processes are in general less known. Developing a cryopreservation protocol for the latter is far more challenging.

The most commonly used model organisms is a quite restrictive list; on one side, it makes sense that scientists all over the world use the same model organisms, since data will be easily to compare, but this list should not be exclude emerging or specific model organisms. The most used model organisms representing different animal taxa are: mice (whose germaplasm and embryos have multiple cryopreservation protocols published like, [54]), drosophila [55], zebrafish (whose cryopreservation protocol is under study but the cryopreservation of fish oocytes or embryos hasn't been achieved yet) or, in the case of marine invertebrates, oysters, e.g., [22,56]. Cryopreservation of these model organisms in genome banks is extremely useful for biological research and the biomedical community [57].

\subsection{Cryopreservation of Sea Urchin Gametes, Embyros and Larvae-Historical Landmark Events}

Within marine invertebrate cryopreservation published research, mollusks and echinoids together constitute $72 \%$ of the research effort. Mollusks represent most of the work published, being oysters the best studied due to their global economic importance. In particular, Crassostrea gigas represents $64 \%$ of the total work published on oysters, followed by Crassostrea virginica with 12\% [58].

Echinoids have attracted much less interest; sea urchins alone represent $28 \%$ of the publications on marine invertebrate cryopreservation. All of the published work that has been done covers the 11 different species listed here: Hemicentrotus pulcherrimus, Strongylocentrotus nudus, Strongylocentrotus intermedius, Anthiocidaris crassispina, Loxechinus albus, Tetrapigus niger, Strongylocentrotus droebachiensis, Evechinus chloroticus, Paracentrotus lividus, Pseudocentrotus depressus, Urechis unicintus. Regarding the cell types, work published on sea urchin cryopreservation, $41.2 \%$ are papers about sperm cryopreservation, $29.4 \%$ are on larvae, $17.6 \%$ embryo, and only $11.76 \%$ regarding oocyte cryopreservation (Table 1 ).

Table 1. List of cryopreservation studies published on Sea urchins sperm, oocytes, embryos and larvae from 1960 to 2015. Survival assessment results shown are the highest ones reported in each study. Cryoprotecting agents (CPAs) acronyms: $\mathrm{Me}_{2} \mathrm{SO}$ : Dimethyl sulfoxide, EG: Ethylene glycol, PG: Propylene glycol, MetOH: Methanol, Gly: Glycine, G: Glycerol, AceT: Acetamide, SUC: Sucrose, TRE: Trehalose, PVP: Polyvinylpyrrolidone.

\begin{tabular}{|c|c|c|c|c|}
\hline Species & Cell & Paper & Cryopreservation Protocol & $\begin{array}{c}\text { Survival } \\
\text { Assessment }\end{array}$ \\
\hline \multirow{2}{*}{ Hemicentrotus pulcherrimus } & Embryos & $\begin{array}{c}\text { Asahina and } \\
\text { Takahashi }[35,36]\end{array}$ & $\begin{array}{l}\mathrm{Me}_{2} \mathrm{SO} 1.5 \mathrm{M} \text {. Cooling rates } \\
10-40{ }^{\circ} \mathrm{C} \cdot \mathrm{min}^{-1} \text {. Thawing in air } \\
15^{\circ} \mathrm{C} \cdot \mathrm{min}^{-1}\end{array}$ & $\begin{array}{l}10 \% \text { Development } \\
\text { to larvae }\end{array}$ \\
\hline & Larvae & $\begin{array}{l}\text { Asahina and } \\
\text { Takahashi [31] }\end{array}$ & $\begin{array}{l}\mathrm{Me}_{2} \mathrm{SO} 1 \mathrm{M} \text {. Cooling rates } \\
10-40^{\circ} \mathrm{C} \cdot \mathrm{min}^{-1} \text {. Thawing in air } \\
15^{\circ} \mathrm{C} \cdot \mathrm{min}^{-1}\end{array}$ & $90 \%$ Survival \\
\hline
\end{tabular}


Table 1. Cont.

\begin{tabular}{|c|c|c|c|c|}
\hline Species & Cell & Paper & Cryopreservation Protocol & $\begin{array}{c}\text { Survival } \\
\text { Assessment }\end{array}$ \\
\hline \multirow{5}{*}{ Strongylocentrotus intermedius } & \multirow{3}{*}{ Embryos } & $\begin{array}{c}\text { Asahina and } \\
\text { Takahashi }[36,59]\end{array}$ & $\begin{array}{l}\text { EG } 1.5 \mathrm{M} \text {. Cooling rate } \\
10^{\circ} \mathrm{C} \cdot \mathrm{min}^{-1} \text {. Thawing rate } \\
7^{\circ} \mathrm{C} \cdot \mathrm{min}^{-1}\end{array}$ & $\begin{array}{l}90 \% \text { Active } \\
\text { swimming }\end{array}$ \\
\hline & & Gakhova et al. [60] & $\begin{array}{l}\mathrm{Me}_{2} \mathrm{SO} 1-1.5 \mathrm{M} \text {. Cooling rate } \\
6-8{ }^{\circ} \mathrm{C} \cdot \min ^{-1} . \text { Thawing in water } \\
\text { bath } 19^{\circ} \mathrm{C}\end{array}$ & $\geqslant 90 \%$ survival \\
\hline & & Naidenko et al. [34] & $\begin{array}{l}\mathrm{Me}_{2} \mathrm{SO} 1 \mathrm{M}+1 \mathrm{mg} \cdot \mathrm{mL}^{-1} \\
\text { Antioxidant. Acording to } \\
\text { Gakhova et al. }(1988)^{*}\end{array}$ & $\begin{array}{l}60 \% \text { swimming } \\
\text { post-thaw, } 1 \% \\
\text { develop. }\end{array}$ \\
\hline & \multirow[t]{2}{*}{ Larvae } & $\begin{array}{l}\text { Asahina and } \\
\text { Takahashi [59] }\end{array}$ & $\begin{array}{l}\text { EG } 1.5 \mathrm{M} \text {. Cooling rate } \\
10^{\circ} \mathrm{C} \cdot \mathrm{min}^{-1} . \text { Thawing rate } \\
7^{\circ} \mathrm{C} \cdot \mathrm{min}^{-1}\end{array}$ & $90 \%$ Development \\
\hline & & Naidenko et al. [34] & $\begin{array}{l}\mathrm{Me}_{2} \mathrm{SO} 1 \mathrm{M}+1 \mathrm{mg} \cdot \mathrm{mL}^{-1} \text { Antiox., } \\
\text { Acording to Gakhova et al. (1988)* }\end{array}$ & $\begin{array}{l}20 \% \text { Active } \\
\text { Swimming }\end{array}$ \\
\hline Anthocidaris crassispina & Sperm & Wu et al. [62] & $\begin{array}{l}\text { According to H. Kurokura et al. } \\
(1989)^{*}\end{array}$ & $10 \%$ Motility \\
\hline Loxechinus albus & Larvae & Barros et al. [35] & $\begin{array}{l}\mathrm{Me}_{2} \mathrm{SO} 1 \mathrm{M} \text {. Two step cooling rate } \\
3: 10^{\circ} \mathrm{C} \cdot \mathrm{min}^{-1} \text {. Thawing in water } \\
\text { bath } 15^{\circ} \mathrm{C} 30 \mathrm{~s}\end{array}$ & $\begin{array}{l}77 \% \text { Survival after } \\
24 \text { h., } 55 \% \text { Survival } \\
\text { after } 21 \mathrm{~d}\end{array}$ \\
\hline Evechinus chloroticus & Larvae & Adams et al. [38] & $\begin{array}{l}\mathrm{Me}_{2} \mathrm{SO} 1.5 \mathrm{M} \text {. Cooling rate } \\
2.5^{\circ} \mathrm{C} \cdot \mathrm{min}^{-1} \text {. Thawing in water } \\
\text { bath } 15^{\circ} \mathrm{C} 30 \mathrm{~s}\end{array}$ & 91\% Motility \\
\hline \multirow{3}{*}{ Paracentrotus lividus } & Sperm & Fabbrocinni et al. [64] & $\begin{array}{l}1 \mathrm{M} \mathrm{Me}_{2} \mathrm{SO} \text {. Cooling rate } \\
20^{\circ} \mathrm{C} \cdot \mathrm{min}^{-1} \text {. Thawing rate } \\
15^{\circ} \mathrm{C} \cdot \mathrm{min}^{-1}\end{array}$ & $\begin{array}{l}90 \% \text { motility, } 50 \% \\
\text { Normal Larvae }\end{array}$ \\
\hline & Oocytes & $\begin{array}{c}\text { Paredes and Bellas } \\
\text { [43] }\end{array}$ & $\begin{array}{l}\mathrm{Me}_{2} \text { SO NOEC: } 0.5 \mathrm{M}, \mathrm{EG} \text { NOEC: } 1 \mathrm{M} \text {, } \\
\text { PG NOEC: } 0.68 \mathrm{M}\end{array}$ & $\begin{array}{l}\text { Toxicity tests } \\
\text { of CPAs }\end{array}$ \\
\hline & Embryos & $\begin{array}{l}\text { Bellas and Paredes } \\
\text { [39], Paredes and } \\
\text { Bellas }[10,21]\end{array}$ & $\begin{array}{l}\mathrm{Me}_{2} \mathrm{SO} 1.5 \mathrm{M}+0.04 \mathrm{M} \text { TRE. } \\
1^{\circ} \mathrm{C} \cdot \mathrm{min}^{-1} . \text { Thawing in water } \\
\text { bath } 18^{\circ} \mathrm{C}\end{array}$ & $\begin{array}{l}50 \%-80 \% \text { Normal } \\
\text { larvae after } 96 \mathrm{~h} . \\
25 \% \text { settlement }\end{array}$ \\
\hline Pseudocentrotus depressus & Sperm & Kurokura et al. [65] & $\begin{array}{l}\text { 1.4 } \mathrm{M} \mathrm{Me}_{2} \mathrm{SO} \text {. Cooling rate } 6 \\
{ }^{\circ} \mathrm{C} \cdot \mathrm{min}^{-1} \text {. Thawing rate } 10-15 \\
{ }^{\circ} \mathrm{C} \cdot \mathrm{min}^{-1}\end{array}$ & $\begin{array}{l}13 \%-33 \% \\
\text { Fertilization }\end{array}$ \\
\hline
\end{tabular}

The first study published in sea urchin cryopreservation dates back to 1961 by Asahina [66] (Table 1) using unfertilized S. nudus oocytes to study intracellular freezing, when oocytes were held at $-16{ }^{\circ} \mathrm{C}$ without using any cryoprotective additive. Six years later, Asahina [67] published another paper on freezing injury on sea urchin oocytes. In both, he studied the mechanisms of freezing injury caused by formation of ice crystals inside the cell or in the extracellular solution, establishing that S. nudus cells were quite sturdy, resisting exposure to relatively low temperatures $\left(-10\right.$ to $\left.-16^{\circ} \mathrm{C}\right)$, but on a short period of time (less than $6 \mathrm{~h}$ ); when exposed to low temperatures for longer periods, though many oocytes looked structurally intact, once fertilized, all of them failed to develop.

Lanan [68], working on oyster sperm, was the first to publish in the field of marine invertebrate cryopreservation. In 1973, Dunn and McLachlan [59] (Table 1) cryopreserved the sperm of 
S. droebachiensis with 1.5 $\mathrm{M} \mathrm{Me}_{2} \mathrm{SO}$. In their research, Dunn and McLachan [59] reported that after cryopreservation sperm's motility was compromised. However, by increasing the sperm-oocyte ratio, they could achieve $95 \%$ fertilization.

A few years later, Asahina and Takahashi [32,57] published a paper on the sperm and embryo cryopreservation of H. pulcherrimus, S. intermedius and S. nudus using $1.5 \mathrm{M} \mathrm{Me}_{2} \mathrm{SO}$ (Table 1). They observed the same effect of reduced post-thaw sperm motility as Dunn and McLachan [59] reported and the resulting fertilization rate was $75 \%$. Those fertilized embryos were incubated and developed normally to pluteus larval stage. Cryopreserved embryos, on the contrary, survived but showed a higher degree of abnormalities and developmental delay that had fatal results within 3 days post thawing.

In the 90's, Naidenko et al. [33,34] evaluated the viability of embryos and larvae of S. intermedius cryopreserved in $1.5 \mathrm{M} \mathrm{Me}_{2} \mathrm{SO}$ alone and in combination with the antioxidant pigment Echinochrome-A isolated from sea urchins (Table 1). For the first time, a complete larval rearing of the cryopreserved embryos was carried out, and, despite reporting that larvae post-thaw presented severe abnormalities, they found that a symbolic $0.1 \%-0.25 \%$ of embryos (cryopreserved at blastula stage) metamorphosed into juveniles. Pluteus larvae endured cryopreservation better than earlier embryos, and the larvae acquired a higher than normal pigmentation when cryopreserved using a combination of $\mathrm{Me}_{2} \mathrm{SO}$ and antioxidant pigments with a $100 \%$ survival after 4 days incubation.

In 2003, Adams et al. [69] studied for the first time membrane permeability characteristics and osmotic tolerance limits and their application in cryopreservation of oocytes of the sea urchin E. chloroticus (Table 2). In 2004, this research group published extensive work on the effects of cryopreservation on sperm cells. They concluded that lower concentrations of $\mathrm{Me}_{2} \mathrm{SO}(0.35-1.06 \mathrm{M})$ were more effective in preserving the fertilization ability, whereas higher concentrations preserved mitochondrial function and membrane integrity, items that were crucial for sperm motility and sperm-oocyte recognition. A cryopreservation study with sea urchin larvae from E. chloroticus [38] pointed out that four-arm pluteus larvae could be reared to settlement, achieving a $6 \%$ survival after 30 days incubation, despite the fact that many larvae showed a high degree of abnormalities. This paper has reported the highest survival of sea urchin embryo or larvae to date.

Table 2. Permeability parameters for sea urchin oocytes. Selected data from [69-72].

\begin{tabular}{|c|c|c|c|c|}
\hline Species & CPA & $T\left({ }^{\circ} \mathrm{C}\right)$ & $\mathrm{Lp}(\mu \mathrm{m} / \mathrm{min} / \mathrm{atm})$ & Ps $\left(10^{-3} \mathrm{~cm} / \mathrm{min}\right)$ \\
\hline \multirow{8}{*}{ Evechinus chloroticus } & \multirow{2}{*}{ Water } & 20 & $0.191 \pm 0.001$ & \\
\hline & & 10 & $0.097 \pm 0.007$ & \\
\hline & \multirow{2}{*}{$\mathrm{Me}_{2} \mathrm{SO} 1.5 \mathrm{M}$} & 20 & $0.169 \pm 0.009$ & $0.295 \pm 0.022$ \\
\hline & & 10 & $0.072 \pm 0.004$ & $0.071 \pm 0.009$ \\
\hline & \multirow{2}{*}{ EG $1.5 \mathrm{M}$} & 20 & $0.167 \pm 0.010$ & $0.261 \pm 0.037$ \\
\hline & & 10 & $0.057 \pm 0.003$ & $0.055 \pm 0.006$ \\
\hline & \multirow{2}{*}{ PG $1.5 \mathrm{M}$} & 20 & $0.153 \pm 0.008$ & $0.526 \pm 0.042$ \\
\hline & & 10 & $0.070 \pm 0.004$ & $0.066 \pm 0.006$ \\
\hline \multirow{4}{*}{ Arbacia punctulata } & \multirow{2}{*}{ Water } & 21 & 0.107 & \\
\hline & & 12 & 0.043 & \\
\hline & \multirow{2}{*}{ EG $0.5 \mathrm{M}$} & 20.3 & $\mathrm{n} / \mathrm{a}$ & $0.32 \pm \mathrm{n} / \mathrm{a}$ \\
\hline & & 10.2 & $\mathrm{n} / \mathrm{a}$ & $0.09 \pm \mathrm{n} / \mathrm{a}$ \\
\hline
\end{tabular}

Paredes and Bellas [43] working with sea urchin P. lividus studied the toxicity of cryoprotective agents for oocytes, fertilized oocytes and early embryos (Figure 2). Using EG, PG, $\mathrm{Me}_{2} \mathrm{SO}, \mathrm{TRE}$ and PVP, they calculated the toxic thresholds (see Section 2, compounds with cryoprotective action). On the basis of the NOEC (No Observed Effect Concentration) and LOEC (Lowest Observed Effect Concentration) calculated levels, EG was the least toxic CPA. However, in cryopreservation tests, $\mathrm{Me}_{2} \mathrm{SO}$ resulted into highest survivals post-freeze. This was in accordance with all the previously published papers. 
Paredes and Bellas [10,21]) established a protocol for blastula cryopreservation using $1.5 \mathrm{M} \mathrm{Me}_{2} \mathrm{SO}$ with $40 \mathrm{mM}$ TRE obtaining larvae that developed more slowly than unfrozen controls within the first $48 \mathrm{~h}$, after which the larvae grew, achieving, on average, $50 \%$ of the size of the unfrozen controls after $96 \mathrm{~h}$ (Figure 2, Table 1). The percentage of abnormalities during larval development is minimal and, once incubated, to juveniles. After 20 days post-thaw, $25 \%$ of the larvae settled.

As Table 1 reports, the three most successful cryopreservation protocols for sperm cryopreservation are those reported by: Barros et al. [35,36] for T. niger equilibrating the sperm for $15 \mathrm{~min}$. at $20^{\circ} \mathrm{C}$ with $1.2 \mathrm{M} \mathrm{Me}_{2} \mathrm{SO}$ using $0.25 \mathrm{~mL}$ straws, the cooling rate used was $6{ }^{\circ} \mathrm{C} \cdot \mathrm{min}^{-1}$ to $-20^{\circ} \mathrm{C}$ and $25^{\circ} \mathrm{C} \cdot \mathrm{min}^{-1}$ to $-150{ }^{\circ} \mathrm{C}$, and the straws were then plunged into liquid nitrogen. Thawing was performed by immersion in a water bath at $17^{\circ} \mathrm{C}$ for $12 \mathrm{~s}$. Obtaining $96 \%$ fertilization rate and $56 \%$ development of the fertilized embryos after $24 \mathrm{~h}$. Adams et al. [37] obtained $85 \%$ fertilization using cryopreserved sperm of E. chloroticus when using lower concentrations of CPA, incubated between 28 and $41 \mathrm{~min}$ at $0{ }^{\circ} \mathrm{C}$ prior to cooling at $50{ }^{\circ} \mathrm{C} \cdot \mathrm{min}^{-1}$, and thawing was done by immersion in a water bath at $15^{\circ} \mathrm{C}$ for $30 \mathrm{~s}$. Fabrocinni et al. [64] obtained cryopreserved P. lividus sperm presenting $90 \%$ motility and $50 \%$ normal larvae development after $48 \mathrm{~h}$ using $1 \mathrm{M} \mathrm{Me}_{2} \mathrm{SO}+0.04 \mathrm{M} \mathrm{TRE}$, with a cooling rate of $20^{\circ} \mathrm{C} \cdot \mathrm{min}^{-1}$, and thawing was performed by immersion in a water bath of $30^{\circ} \mathrm{C}$ for $2 \mathrm{~s}$.

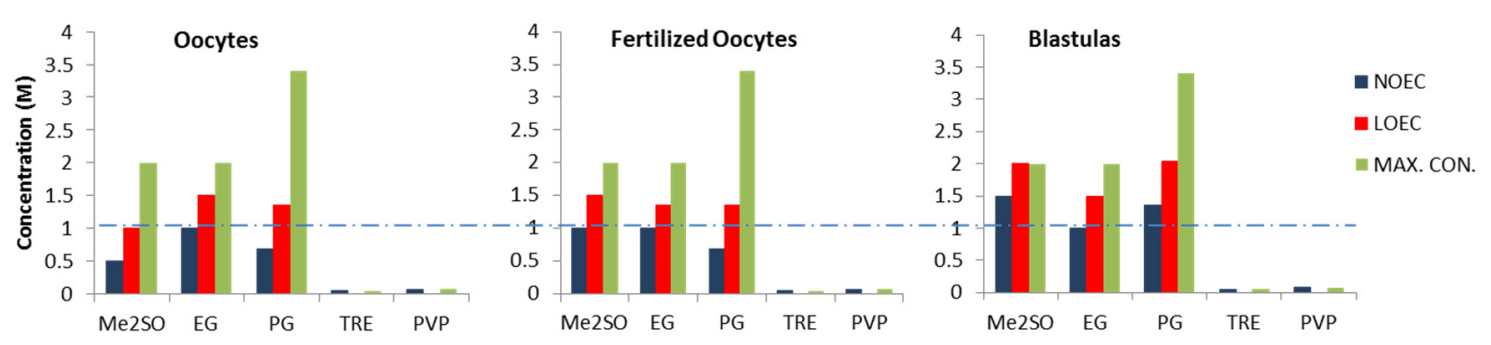

Figure 2. NOEC, LOEC and Highest tested concentration (Max. Con.) For three cell types for $P$. lividus (Data from $[39,43]$ ). Blue line at $1 \mathrm{M}$ represents on average the most used concentration in literature. Results obtained by the evaluation of normal shape and development of embryos for $48 \mathrm{~h}$ exposed to increasing dose of these chemical compounds. Common abnormalities produced from this exposure can range from complete inhibition of development, abnormal shape or swimming behavior to abnormal growth. There are no protocols described for sea urchin oocyte cryopreservation, although there are some studies about membrane permeability and sensitivity to cryoprotecting agents.

The most successful embryo cryopreservation protocol for sea urchins has been reported by Paredes and Bellas [10,21] using 8-h-old P. lividus blastulas, with a 15 min stepwise addition of $1.5 \mathrm{M}$ $\mathrm{Me}_{2} \mathrm{SO}$ plus $40 \mathrm{mM}$ TRE at $20^{\circ} \mathrm{C}$, using $2 \mathrm{~mL}$ cryovials and a cooling rate of $1^{\circ} \mathrm{C} \cdot \mathrm{min}^{-1}$ to $-80^{\circ} \mathrm{C}$ (with seeding for $2 \mathrm{~min}$ at $-12{ }^{\circ} \mathrm{C}$ ). Thawing was performed by immersion in a $18^{\circ} \mathrm{C}$ water bath until the ice melted and cryoprotecting agents were removed stepwise in $12 \mathrm{~min}$. This protocol yielded $80 \%-50 \%$ normal larvae after $96 \mathrm{~h}$, and those larvae were at least $50 \%$ the size of the unfrozen controls and produced a settlement to juveniles of $25 \%$ in comparison to controls.

Barros et al. [35] published the most successful protocol for sea urchin larvae cryopreservation so far, using the sea urchin L. albus with $1 \mathrm{M} \mathrm{Me}_{2} \mathrm{SO}$ (equilibration time of $20 \mathrm{~min}$ at $0{ }^{\circ} \mathrm{C}$ ). With a two-step cooling rate of $3{ }^{\circ} \mathrm{C} \cdot \mathrm{min}^{-1}$ to $-10^{\circ} \mathrm{C}$ and $10{ }^{\circ} \mathrm{C} \cdot \mathrm{min}^{-1}$ to $-150{ }^{\circ} \mathrm{C}$. Thawing in a water bath at $15{ }^{\circ} \mathrm{C}$ for $30 \mathrm{~s}$ resulted in $77 \%$ survival after $24 \mathrm{~h}$ and $55 \%$ survival after 21 days.

\subsection{Cryopreservation and Cryoinjuries}

There is general an agreement that membranes are often damaged during the freezing process $[56,73,74]$, and sea urchins are probably not an exception. Although there is research published on sea urchin embryos reporting positive results after freezing, such as an initial $90 \%$ survival reported with $H$. pulchehimus, S. intermedius and S. nudus embryos, the resulting larvae suffered severe abnormalities, and development was impaired after only three days $[31,32,59,75]$. Cryopreserved 
embryos were able to be reared to juveniles for $S$. intermedius $[33,34,61]$ and, despite suffering some abnormalities, $0.1 \%-0.2 \%$ survived to settlement. An encouraging cryopreservation study was published by Adams et al. [38] on E. chloroticus four-arm Pluteus larvae, although many larvae showed membrane damage they obtained $6 \%$ post-thaw larvae settlement (30 days of larval rearing), which was a significant improvement of the previous protocols published. If the cryopreservation protocol does not work, the cells that survive-if any-will present lethal abnormalities that will impair development and cause death within a few hours or days.

The cryopreservation protocol described for P. lividus embryos [10,39] yields a good blastula survival (over $50 \%$ after cryopreservation), less than $25 \%$ abnormalities, but interestingly cryopreserved embryos showed a delay in development when compared with fresh controls. Cryopreserved embryos grow only $20 \%$ of the control size in the first $48 \mathrm{~h}$, mostly remaining as blastulas or gastrulas, but, from that point on, larvae start to develop and grow faster. The percentage of larval growth, compared to controls at $96 \mathrm{~h}$, was $50 \%$ growth on average, but with significant variability during the reproductive season (the highest reported was over $80 \%$ of control size).

This phenomenon of growth delay during the first hours post-cryopreservation has also been seen in other marine embryos or larvae as mussels or oysters $[58,76]$. However, the question of what this means remains unanswered. It is not clear what is occurring within the first hours of embryo incubation post-cryopreservation. During the first hours post-cryopreservation and thawing, several processes might be happening synchronously causing the delay of growth. First, it might be due to the slow activation of metabolism following the exposure to cold temperatures, since, when cells are stored in cryogenic temperatures, all metabolic reactions are on hold, and it seems reasonable to suggest that reactivating the cellular mechanisms might take time since metabolic reactions are temperature-dependent. Secondly, there might be an activation of the membrane-restoration mechanisms present in sea urchins [77] because it is well-known that the membrane fluidity and integrity might be reduced due to the cryopreservation process; this has been detected in human sperm and mouse oocytes [78,79]. It is also well-known that there is an active production of Reactive Oxygen Species (ROS) post-cryopreservation for sperm cells of several species [80]. Therefore, the development delay might be related to using the vitellogenic energy remaining to activate mechanisms to deal with ROS instead of growth [78-80]. These processes are very likely quite general to cells during the freeze-thawing process but have not been studied in marine organisms.

When incubated for longer periods, larvae that survived cryopreservation [21] will successfully grow (though a little slower) and reach the four-arm pluteus stage after $96 \mathrm{~h}$ of incubation (when controls reach this development stage after $48 \mathrm{~h}$ ). When a complete larval rearing with cryopreserved embryos was carried out, it resulted in $29 \%$ survival by day 20 and a settlement percentage of $7 \%$ by day 18 post-competence ( $71 \%$ survival and $25 \%$ settlement in comparison to fresh controls) [10]. This protocol for sea urchin embryos is the only one published that produces high viable outcome with embryos that can grow into larvae and metamorphose and settle into juveniles.

\subsection{Sea Urchin Cell and Membrane Characteristics}

During cryopreservation cells undergo dehydration and osmotic volume excursions, and some cells are more sensitive than others. The volumetric changes caused by the addition and removal of the cryoprotecting agents and the freezing process itself can be damaging if they exceed the osmotic tolerance limits. In order to formulate optimal methods of loading and unloading cryoprotecting agents to minimize damage, there are some cell characteristics that need to be known: Surface area to volume ratio, water permeability (Lp), solute permeability (Ps), their activation energies (Ea) and the osmotically inactive volume of the cell $(\mathrm{Vb})$. These parameters are related as follows:

$$
\begin{gathered}
\mathrm{dV}_{\mathrm{w}} / \mathrm{dt}=\operatorname{LpART}\left(\mathrm{M}^{\mathrm{i}}-\mathrm{M}^{\mathrm{e}}\right) \\
\mathrm{dN}_{\mathrm{s}} / \mathrm{dt}=\operatorname{Ps} \mathrm{A}\left(\mathrm{a}_{\mathrm{s}}^{\mathrm{e}}-\mathrm{a}_{\mathrm{s}}^{\mathrm{i}}\right)
\end{gathered}
$$




$$
\mathrm{V}=\mathrm{V}_{\mathrm{w}}+\mathrm{V}_{\mathrm{b}}
$$

These are water permeability and solute permeability equations for modeling water and solute movements through membranes, where $\mathrm{V}$ represents the cell volume, $\mathrm{V}_{\mathrm{w}}$ is the water volume inside of the cell, $t$ is time, A is the surface area of the cell, $\mathrm{R}$ is the universal gas constant, $\mathrm{T}$ is the absolute temperature, $\mathrm{M}^{\mathrm{e}}$ and $\mathrm{M}^{\mathrm{i}}$ are the external and internal osmolality. Ns is the number of osmoles of permeating solutes, and $\mathrm{a}_{\mathrm{s}}$ and $\mathrm{a}_{\mathrm{s}}^{\mathrm{i}}$ are the external and internal activity of the permeating solutes.

The water and solute permeability of sea urchin cells have been studied by McCutcheon and Lucké [70,71], Stewart and Jacobs [72], Leitch [81], Lucké et al. [82], and Adams et al. [69]. It has been proved that sea urchin Evechinus chloroticus oocytes [69] follow the Boyle-van't Hoff relationship, which states that volume varies linearly as a function of the reciprocal of the osmolality. Sea urchin oocytes behave as ideal osmometers within the range of $0.6-2.0$ Osm. This idea of sea urchin oocyte membranes having a perfect semipermeable membrane had also been pointed out by McClutcheon et al. [70] when studying the permeability of Arbacia punctulata oocytes. The permeability of a cell to water will vary with temperature, but will also depend on the membrane composition and method of transport (transport through channels or membrane diffusion); therefore, it may vary among cells types. The same is true for the solute permeability (Ps) (Table 2).

Oocyte volume varies widely among sea urchin species. Evechinus chloroticus oocytes have a volume of $7.57 \times 10^{-6} \mathrm{~cm}^{3}, 36.7 \%, 30.3 \%$ of which is osmotically inactive volume $\left(\mathrm{V}_{\mathrm{b}}\right)$ for oocytes and fertilized oocytes, respectively (Adams et al., 2003). Paracentrotus lividus oocytes volume is $3.94 \times 10^{-6} \mathrm{~cm}^{3}$ and, according to Leitch [81], 22.6\% is their osmotically inactive volume. Similarly, Strogylocentrotus purpuratus oocytes have a volume of $2.60 \times 10^{-7} \mathrm{~cm}^{3}$ with a $24.5 \%$ osmotically inactive volume [81] Strongylocentrotus franciscanus oocytes are slightly higher, with a volume of $11.6 \times 10^{-7} \mathrm{~cm}^{3}$, but their osmotically inactive volume is lower, $18 \%$ [81].

There are almost no data available regarding all those parameters listed in Section 3.3 for oocytes, neither for other types of cells, such as sperm, embryos or larvae, nor for the remaining sea urchins species insofar as the author is aware. Therefore, until these factors are studied, we can only assume that those parameters could be extrapolated to other sea urchin species and similar cells for modeling volumetric responses with the appropriate caution about the interpretation of the results.

\section{Conclusions}

Sea urchins are being collected, used and kept in research facilities all over the world. However, sea urchins are not just useful as research model organisms; there is a real interest in sea urchin aquaculture [12-16], population enhancement for fisheries conservation [20], ecological conservation [83], and marine pollution assessment $[7,8]$.

Sea urchins are a very useful model organism in that they are easy to obtain from nature, easy to work with, very fertile, and their embryos and larvae are easy to culture. On the other hand, due to their marked reproductive seasonality, it is impossible to collect mature sea urchins year-round, and maintaining a stock of mature sea urchins all year is very difficult and expensive when possible. The establishment of biobanks in those facilities where sea urchins are used as model organisms would help overcome the constraint of year-round biological material supply. However, it should be noted that sea urchin biobanks could also be of potential interest for the industries of aquaculture, fishery conservation and environmental monitoring.

It is therefore remarkable that, despite some of the pioneering work in cryopreservation that was done with marine invertebrates such as oysters [68] and sea urchins [31] there has been little research carried out in sea urchin cryopreservation and biobanking thereafter. Only in recent years have researchers re-discovered the usefulness of its cryopreservation and increased their interest in biobanking for different purposes [10,21,37-40,43,61,64].

Currently, sea urchin sperm can be cryopreserved with $90 \%$ motility and $95 \%$ fertilization [64] on P. lividus; on the other hand, results of sea urchin oocyte cryopreservation results are far less optimistic $[37,43]$. Oocytes are chill and CPA-sensitive. As an alternative, there has been an intensive 
research interest for embryo and larvae cryopreservation with positive results [33,38,39]. Embryos and larvae are the most tolerant to cryopreservation, with oocytes being the most sensitive. Still, all the knowledge available is restricted to the 11 species hitherto cryopreserved. In all cases, the most efficient conditions for embryo or larvae cryopreservation are slow cooling rates (less than $7^{\circ} \mathrm{C} \cdot \mathrm{min}^{-1}$ ), the seeding of the samples, and $\mathrm{Me}_{2} \mathrm{SO}$ as cryoprotecting agent (concentrations ranging from 1 to $1.5 \mathrm{M}$ ). There is a lack of knowledge of the membrane permeability characteristics of most of the sea urchins species, though some similar results could be expected when applying protocols already developed to other species. Without the knowledge about cell characteristics and sensitivity, this information can only be used as a preliminary approach, as it has been extensively proved that cryopreservation protocols are species and cell-specific. An intense research effort is needed towards widening the knowledge of sea urchin membrane parameters, modeling the addition and dilution of cryoprotecting agents, studies of membrane composition, and long-term viability of cryopreserved cells in order to increase the number of species that are available to biobank and use when necessary.

Acknowledgments: The author would like to acknowledge Juan Bellas, Ricardo Beiras and Damian Costas from Instituto Español de Oceanografia and University of Vigo (Spain) for sharing their expertise about sea urchins, Serean Adams from Cawthron Institute (New Zealand) and her cryoteam for their inspiration and knowledge on marine cryopreservation, and Mazur from University of Tennessee (USA) for providing the necessary background with respect to the fundamentals of cryobiology.

Conflicts of Interest: The author declares no conflict of interest.

\section{References}

1. World Registry of Marine Species (WORMS). Available online: http://www.marinespecies.org/ (accessed on 30 January 2015).

2. Boudouresque, C.F.; Verlaque, M. Ecology of Paracentrotus lividus. In Edible Sea Urchins: Biology and Ecology, 2nd ed.; Lawrence, J., Ed.; Elsevier: Amsterdam, The Netherlands, 2007; pp. 243-285.

3. Lawrence, J.M. Developments in Aquaculture and Fisheries Science. In Sea Urchins: Biology and Ecology, 3rd ed.; Elsevier: Amsterdam, The Netherlands, 2007; Volume 38.

4. Gilbert, S.F. Early development of sea urchins. In Developmental Biology, 9th ed.; Sinuauer Associates, Inc.: Sunderland, MA, USA, 2000.

5. Kominami, T.; Takata, H. Gastrulation in the sea urchin embryo: A model system for analyzing the morphogenesis of a monolayered epithelium. Dev. Growth Differ. 2004, 46, 309-326. [CrossRef] [PubMed]

6. Epel, D.; Cole, B.; Hamdoun, A.; Thurber, R.V. The sea urchin embryo as a model for studying efflux transporters: Roles and energy cost. Mar. Environ. Res. 2006, 62, S1-S4. [CrossRef] [PubMed]

7. Beiras, R.; Fernandez, N.; Bellas, J.; Besada, V.; Gonzalez-Quijano, A.; Nunes, T. Integrative assessment of marine pollution in Galician estuaries using sediment chemistry, mussel bioaccumulation, and embryo-larval toxicity bioassays. Chemosphere 2003, 52, 1209-1224. [CrossRef]

8. Bellas, J.; Fernandez, N.; Lorenzo, I.; Beiras, R. Integrative assessment of coastal pollution in Ría coastal system (Galicia, NW Spain): Correspondence between sediment chemistry and toxicity. Chemosphere 2008, 72, 826-835. [CrossRef] [PubMed]

9. Dinnel, P.A.; Link, J.M.; Stober, Q.J.; Letorneau, M.W.; Roberts, W.E. Comparatives sensitivity of sea urchin sperm bioassays to metals and pesticides. Arch. Environ. Contam. Toxicol. 1989, 18, 748-755. [CrossRef] [PubMed]

10. Paredes, E.; Bellas, J. The use of cryopreserved sea urchin embryos (Paracentrotus lividus) in marine quality assessment. Chemosphere 2015, 128, 278-283. [CrossRef] [PubMed]

11. Andrew, N.L.; Ballesteros, Y.E.; Bazhin, A.G.; Creaser, E.P.; Barnes, D.K.A.; Botsford, L.W.A.; Bradbury, A.; Campbell, J.D.; Dixon, S.; Eirnarsson, P.K.; et al. Status and Management of world sea urchin fisheries. In Oceanography and Marine Biology: An Annual Review; Barnes, H., Gibson, R.N., Barnes, M., Atkingson, R.J.A., Eds.; Taylor and Francis: Abingdon, UK, 2002; Volume 40, pp. 343-426.

12. James, P.J. A comparison of roe enhancement of the sea urchin Evechinus chloroticus in sea-based and land-based cages. Aquaculture 2006, 253, 290-300. [CrossRef] 
13. George, S.B.; Lawrence, J.M.; Lawrence, A.L.; Smiley, J.; Plank, L. Carotenoids in the adult diet enhance egg and juvenile production in the sea urchin Lytechinus variegatus. Aquaculture 2001, 199, 353-369. [CrossRef]

14. George, S.B.; Lawrence, J.M.; Lawrence, L.A. Complete larval development of the sea urchin Lytechinus variegatus fed artificial feed. Aquaculture 2004, 242, 217-228. [CrossRef]

15. Fernandez, C. Effect of diet on the biochemical composition of Paracentrotus lividus (Echinodermata: Echinoidea) under natural and rearing condition (Effect of diet on Biochemical composition of urchins). Comp. Biochem. Physiol. 1997, 118, 1377-1384. [CrossRef]

16. Christiansen, J.S.; Siikavuopio, S.I. The relationship between feed intake and gonad growth of single and stocked green sea urchin (Strongylocentrotus droebachiensis) in raceway culture. Aquaculture 2007, 262, 163-167. [CrossRef]

17. Fernandez, C.; Boudouresque, C.F. Nutrition of the sea urchin Paracentrotus lividus (Echinodermata; Echinoidea) fed different artificial food. Mar. Ecol. Prog. Ser. 2000, 152, 131-141. [CrossRef]

18. Akiyama, T.; Unuma, T.; Yamamoto, T. Optimun protein level in a purified diet for young red sea urchin Pseudocentrotus depressus. Fish. Sci. 2001, 67, 361-363. [CrossRef]

19. Shpigel, M.; McBride, S.C.; Marciano, S.; Ron, S.; Ben-Amotz, A. Improving gonad color and somatic index in the European sea urchin Paracentrotus lividus. Aquaculture 2005, 245, 101-109. [CrossRef]

20. Gonzalez-Henriquez, N.; Grimon, M.; Catoira, J.L. Cultivo exterior para la repoblación de Paracentotus lividus en las Islas Canarias. Abstr. Congr. Nac. Acuic. 2009, 2, 44-45.

21. Paredes, E.; Bellas, J. Sea urchin (Paracentrotus lividus) cryopreserved embryos survival and growth: Effects of cryopreservation parameters and reproductive seasonality. CryoLetters 2014, 35, 482-494. [PubMed]

22. Adams, S.L.; Smith, J.F.; Tervit, H.R.; McGowan, L.T.; Roberts, R.D.; Achim, R.J.; King, N.G.; Gale, S.L.; Webb, S.C. Cryopreservation of molluscan sperm: Oyster (Crassostrea gigas, Thunberg), mussel (Perna canaliculus) and abalone (Haliotis iris). In Cryopreservation in Aquatic Species, 2nd ed.; The World Aquaculture Society: Baton Rouge, LA, USA, 2011.

23. Zhang, T. Cryopreservation of gametes and embryos of aquatic species. In Life in the Frozen State; Fuller, B.J., Lane, N., Benson, E.E., Eds.; CRC Press: Boca Raton, FL, USA, 2004; pp. 415-136.

24. Mims, S.D.; Tsvetkova, L.I.; Wayman, W.R.; Horváth, A.; Urbányi, B.; Gomelsky, B. Cryopreservation of Sturgeon and Paddlefish sperm. In Cryopreservation of Aquatic Species, 2nd ed.; Tiersch, T.R., Green, C.C., Eds.; World Aquaculture Society: Baton Rouge, LA, USA, 2011; pp. 366-380.

25. Lahnsteiner, F. Cryopreservation protocols for sperm of Salmonid fishes. In Cryopreservation of Aquatic Species, 2nd ed.; Tiersch, T.R., Green, C.C., Eds.; World Aquaculture Society: Baton Rouge, LA, USA, 2011; pp. 409-420.

26. Lin, T.-T.; Chao, N.-H. Cryopreservation of eggs and embryos of shellfish. In Cryopreservation of Aquatic Species, 2nd ed.; Tiersch, T.R., Green, C.C., Eds.; World Aquaculture Society: Baton Rouge, LA, USA, 2011; pp. 604-615.

27. Paniagua-Chavez, C.G.; Buchanan, J.T.; Supan, J.E.; Tiersch, T.R. Cryopreservation of sperm and larvae of the eastern oyster. In Cryopreservation of Aquatic Species, 2nd ed.; Tiersch, T.R., Green, C.C., Eds.; World Aquaculture Society: Baton Rouge, LA, USA, 2011; pp. 595-603.

28. Anchordoguy, T.; Crowe, J.H.; Griffin, F.J.; Clark, W.H., Jr. Cryopreservation of sperm from the marine shrimp Sicyona ingestis. Cryobiology 1988, 25, 238-243. [CrossRef]

29. Gwo, J.C.; Lin, C.H. Preliminary experiments on the cryopreservation of penaeid shrimp (Penaeus japonicus) embryos, nauplii and zoea. Theriogenology 1998, 49, 1289-1299. [CrossRef]

30. Vuthiphandchai, V.; Nimrat, S.; Kotcharat, S.; Bart, A.N. Development of cryopreservation protocol for long-term storage of black tiger shrimp (Pennaeus monodon) spermatophores. Theriogenology 2007, 68, 1192-1199. [CrossRef] [PubMed]

31. Asahina, E.; Takahashi, T. Survival of sea urchin spermatozoa and embryos at very low temperatures. Cryobiology 1977, 14. [CrossRef]

32. Asahina, E.; Takahashi, T. Freezing tolerance in embryos and spermatozoa of the sea urchin. Cryobiology 1978, 15, 122-127. [CrossRef] 
33. Naidenko, T.K.; Gakhova, E.N.; Naidenko, V.P.; Veprintsev, B.N. Evaluation of viability of sea urchin larvae after cryopreservation of embryos. In Biology of Echinodermata; Yanagisawa, T., Yasumasu, I., Oguro, C., Suzuki, N., Motokawa, T., Eds.; A.A. Balkema Publishers: Boca Raton, FL, USA, 1991; pp. 261-269.

34. Naidenko, T.K.; Koltsova, E.A. The use of antioxidant echinochrome-A in cryopreservation of sea urchin embryos and larvae. Russ. J. Mar. Biol. 1998, 24, 203-206.

35. Barros, C.; Muller, A.; Wood, M.J.; Whittingham, D.G. High survival of sea urchin semen (Tetrapigus niger) pluteus larvae (Loxechinus albus) frozen in 1.0 M Me2SO. Cryobiology 1996, 33, 646-651.

36. Barros, C.; Muller, A.; Wood, M.J. High survival of spermatozoa and pluteus larvae of sea urchins frozen in Me2SO. Cryobiology 1997, 35, 341.

37. Adams, S.L.; Hessian, P.A.V. Cryopreservation of Sea Urchin (Evechinus chloroticus) Sperm. Cryoletters 2004, 25, 287-299. [PubMed]

38. Adams, S.L.; Hessian, P.A.; Mladenov, P.V. The potential for cryopreserving larvae of the sea urchin, Evechinus chloroticus. Cryobiology 2006, 52, 139-145. [CrossRef] [PubMed]

39. Bellas, J.; Paredes, E. Advances in the cryopreservation of sea-urchin embryos: Potential application in marine water quality assessment. Cryobiology 2011, 62, 174-180. [CrossRef] [PubMed]

40. Paredes, E.; Bellas, J.; Costas, D. Sea urchin (Paracentrotus lividus) larval rearing-Culture from cryopreserved embryos. Aquaculture 2015, 437, 366-369. [CrossRef]

41. Mazur, P. Principles of cryobiology. In Life in the Frozen State; Fuller, B.J., Lane, N., Benson, E.E., Eds.; CRC Press: Boca Raton, FL, USA, 2004; pp. 3-66.

42. Muldrew, K.; Acker, J.P.; Elliot, J.A.W.; McGann, L.E. The water to ice transition: Implications for living cells. In Life in the Frozen State; Fuller, B.J., Lane, N., Benson, E.E., Eds.; CRC Press: Boca Raton, FL, USA, 2004; pp. 67-108.

43. Paredes, E.; Bellas, J. Cryopreservation of sea urchin embryos (Paracentrotus lividus) applied to marine ecotoxicological studies. Cryobiology 2009, 59, 344-350. [CrossRef] [PubMed]

44. Pegg, D.E. Principles of cryopreservation. In Cryopreservation and Freeze-Drying Protocols. Methods in Molecular Biology; Day, J.G., Stacey, G.N., Eds.; Humana Press: New York, NY, USA, 2007; Volume 368, pp. $39-57$.

45. Dennison, R.S.; Michelet, S.; Godke, R.A. Principles of cryopreservation. In Cryopreservation in Aquatic Species; Tiersch, T.R., Mazik, P.M., Eds.; World Aquaculture Society: Baton Rouge, LA, USA, 2000; pp. 59-74.

46. Leung, L.K.P. Principles of biological cryopreservation. In Fish Evolution and Systematics: Evidence from Spermatozoa; Jamieson, B.G.M., Ed.; Cambridge University Press: New York, NY, USA, 1991; pp. 231-244.

47. Leibo, S.; Songsasen, N. Cryopreservation of gametes and embryos of non-domestic species. Theriogenology 2002, 57, 303-326. [CrossRef]

48. Glenister, P.H.; Whittinham, D.G. Further studies on the effect of radiation during the storage of frozen 8-cell mouse embryos at -196 degrees. J. Reprod. Fertil. 1984, 70, 229-234. [CrossRef] [PubMed]

49. German, A.; Oh, Y.-J.; Schimdt, T.; SchÖn, U.; Zimmerman, H.; Von Briesen, H. Temperature fluctuations during deep Temperature cryopreservation reduce PBMC recovery, viability and T-cell fluctuation. Cryobiology 2013, 67, 193-200. [CrossRef] [PubMed]

50. Shaw, D.M.; Elger, B.S.; Colledge, F. What is a biobank? Differing definitions among biobank stakeholders. Clin. Genet. 2013, 85, 223-227. [CrossRef] [PubMed]

51. National Institute of Health (NIH). Using Model Organisms to Study Health and Disease. Available online: https://www.nigms.nih.gov/Education/Pages/modelorg_factsheet.aspx (accessed on 15 September 2015).

52. Scytable by Nature Education. Available online: http://www.nature.com/scitable/definition/modelorganism-model-genetic-organism-139 (accessed on 15 September 2015).

53. Paredes, E.; Mazur, P. Cryopreservation of model organisms: A great tool for biogeochemistry research. In Proceedings of the 2nd Annual South Eastern Biogeochemistry Symposium, Atlanta, GA, USA, 28-29 March 2015 ; p. 31.

54. Jin, B.; Kleinhans, F.W.; Mazur, P. Survival of mouse approach 100\% after vitrification in 3-fold diluted media and ultra-rapid warming by an IR laser pulse. Cryobiology 2014, 68, 419-430. [CrossRef] [PubMed]

55. Mazur, P.; Cole, K.W.; Hall, J.W.; Schereuders, P.D.; Mahowald, A.P. Cryobiological preservation of Drosophila Embryos. Science 1992, 258, 1932-1935. [CrossRef] [PubMed] 
56. Paredes, E.; Bellas, J.; Adams, S.L. Comparative cryopreservation study of trochophore larvae from two species of bivalves: Pacific oyster (Crassostrea gigas) and Blue mussel (Mytilus galloprovincialis). Cryobiology 2013, 67, 274-279. [CrossRef] [PubMed]

57. Agca, Y. Genome resurce banking of biomedically important laboratory animals. Theriogenology 2012, 78, 1653-1665. [CrossRef] [PubMed]

58. Paredes, E. Exploring the evolution of marine invertebrate cryopreservation- Landmarks, state of the art and future lines of research. Cryobiology 2015, 71, 198-209. [CrossRef] [PubMed]

59. Asahina, E.; Takahashi, T. Cryopreservation of sea urchin embryos and sperm. Dev. Growth Differ. 1979, 21, 423-430. [CrossRef]

60. Gakhova, E.N.; Krast, I.V.; Naidenko, T.K.; Savelieva, N.A.; Bessonov, B.I.; Butsuk, S.V.; Beprintsev, B.N. The development of sea urchin embryos after cryopreservation. Ontogenesis 1988, 19, 175-180.

61. Odintsova, N.A.; Boroda, A.V.; Velansky, P.V.; Kostetsky, E.Y. The fatty acid profile changes in marine invertebrate larval cells during cryopreservation. Cryobiology 2009, 59, 335-343. [CrossRef] [PubMed]

62. Wu, J.-G.; Kurokura, H.; Hirano, R. Hibridation of Pseudocentrotus depressus egg and cryopreserved sperm of Anthocidaris crassipina and the morphology of hybrid larva. Nihon-suisan-gakkai-shi 1990, 56, 749-754. [CrossRef]

63. Dunn, R.S.; McLachlan, J. Cryopreservation of echinoderm sperm. Can. J. Zool. 1973, 51, 666-669. [CrossRef] [PubMed]

64. Fabbrocini, A.; D'Adamo, R.; Pelosi, S.; Oliveira, L.F.J.; Silvestri, F.; Sansone, G. Gamete cryobanks for laboratory research: Developing a rapid and easy to perform protocol for the cryopreservation of the sea urchin Paracentrotus lividus (Lmk, 1816) Spermatozoa. Cryobiology 2014, 69, 149-156. [CrossRef] [PubMed]

65. Kurokura, H.; Yagi, N.; Hirano, R. Studies of cryopreservation of sea urchin sperm. Suisanzoshoku 1990, 37, 215-219.

66. Asahina, E. Intracellular freezing and frost resistance in egg-cells of the sea urchin. Nature 1961, 191, 1263-1265. [CrossRef] [PubMed]

67. Asahina, E. Freezing injury in egg cells of the Sea Urchin. Cell. Inj. Res. Freez. Org. 1967, 2, 211-229.

68. Lanan, J.E. Experimental self-fertilization of the Pacific oyster Crassostrea gigas, using cryopreserved sperm. Genetics 1971, 68, 599-601.

69. Adams, S.L.; Kleinhans, F.W.; Hessian, P.A.; Mladenov, V.P. Membrane permeability characteristics and osmotic tolerance limits of eggs of the sea urchin, Evechinus chloroticus. Cryobiology 2003, 47, 1-13. [CrossRef]

70. McCutcheon, M.; Lucke, B.; Hartline, H.K. The osmotic properties of living cells (eggs of Arbacia punctulata). J. Gen. Physiol. 1931, 40, 393-403. [CrossRef]

71. McCutcheon, M.; Lucké, B. The effect of temperature on permeability to water of resting and of activated cells (unfertilized and fertilized eggs or Arbacia puntulata). J. Cell. Comp. Physiol. 1932, 2, 11-26. [CrossRef]

72. Stewart, D.R.; Jacobs, M.H. The permeability of the egg of Arbacia to ethylene glycol at different temperatures. J. Cell. Comp. Physiol. 1932, 2, 275-283. [CrossRef]

73. Wolfe, J.; Bryant, G. Freezing, drying, and/or vitrification of membrane-solute-water systems. Cryobiology 1999, 39, 103-129. [CrossRef] [PubMed]

74. Simonin, H.; Beney, L.; Gervais, P. Sequence of occurring damages in yeast plasma membrane during dehydration and rehydration: Mechanisms of cell death. Biochim. Biophys. Acta 2007, 1768, 1600-1610. [CrossRef] [PubMed]

75. Ohyama, Y.; Asahina, E. Frost resistance in adult insects. J. Insect Physiol. 1972, 18, 267-282. [CrossRef]

76. Paredes, E.; Adams, S.L.; Tervit, H.R.; Smith, J.F.; McGowan, L.T.; Gale, S.L.; Morrish, J.R.; Watts, E. Cryopreservation of GreenshellTM mussel (Perna canaliculus) trochophore larvae. Cryobiology 2012, 65, 256-262. [CrossRef] [PubMed]

77. McNeil, P.L.; Kirchhausen, T. An emergency response team for membrane repair. Nat. Rev. Mol. Cell Biol. 2005, 6, 499-505. [CrossRef] [PubMed]

78. Giraud, M.N.; Motta, C.; Boucher, D.; Grizard, G. Membrane fluidity predicts the outcome of cryopreservation of human spermatozoa. Hum. Reprod. 2000, 15, 2160-2164. [CrossRef] [PubMed]

79. Ahn, H.F.; Sohn, I.P.; Kwon, H.C.; Jo, D.H.; Park, Y.D.; Min, C.K. Characteristics of the cell membrane fluidity, Actin fibers, and mitochondrial dysfunctions of frozen-thawed two-cell mouse embryos. Mol. Reprod. Dev. 2002, 61, 466-476. [CrossRef] [PubMed] 
80. Baumer, J.; Ball, B.A.; Linfor, J.J.; Meyers, S.A. Reactive Oxygen Species and Cryopreservation promote DNA fragmentation in Equine spermatozoa. J. Androl. 2003, 24, 621-628. [CrossRef]

81. Leitch, J.L. The water exchanges of living cells. J. Cell. Comp. Physiol. 1934, 4, 457-473. [CrossRef]

82. Lucké, B.; Hartline, H.K.; Ricca, R.A. Comparative permeability to water and to certain solutes of the eggs cells of three marine invertebrates, Arbacia, Cumingia and Chaetopterus. J. Cell. Comp. Physiol. 1939, 14, 237-252. [CrossRef]

83. Lafferty, K. Fishing for lobsters indirectly increases epidemics in sea urchins. Ecol. Appl. 2004, 14, 1566-1573. [CrossRef]

(C) 2016 by the author; licensee MDPI, Basel, Switzerland. This article is an open access article distributed under the terms and conditions of the Creative Commons by Attribution (CC-BY) license (http://creativecommons.org/licenses/by/4.0/). 